\title{
PENGARUH MODEL PEMBELAJARAN DISCOVERY LEARNING BERBASIS MIND MAPPING TERHADAP HASIL BELAJAR SISWA
}

\author{
Emilia Seda ${ }^{1}$, Nurul Ain ${ }^{2},{ }^{*}$ Chandra Sundaygara ${ }^{3}$ \\ Program Studi Pendidikan Fisika, Universitas Kanjuruhan Malang 1,2,3 \\ e-mail: chandrakirana@unikama.ac.id
}

\begin{abstract}
Abstrak: Penelitian ini bertujuan untuk mengetahui pengaruh model pembelajaran discovery learning berbasis mind mapping terhadap hasil belajar siswa. Penelitian dilakukan di SMP PGRI 06 Malang. Populasi penelitian adalah seluruh siswa kelas VIII. Sampel dipilih menggunakan teknik purposive sampling, kelas VIII A sebagai kelas eksperimen dan kelas VIII C sebagai kelas kontrol. Jenis penelitian yang digunakan yaitu quasi eksperiment dengan desain "posttest only control group design". Teknik analisis data yang digunakan yaitu uji MANOVA. Hasil analisis data yang diperoleh yaitu: (1) ada perbedaan hasil belajar ranah afektif antara siswa yang belajar menggunakan model pembelajaran discovery learning berbasis mind mapping dengan siswa yang belajar menggunakan model pembelajaran konvensional, (2) ada perbedaan hasil belajar ranah psikomotor antara siswa yang belajar menggunakan model pembelajaran discovery learning berbasis mind mapping dengan siswa yang belajar menggunakan model pembelajaran konvensional, (3) ada perbedaan hasil belajar ranah kognitif antara siswa yang belajar menggunakan model pembelajaran discovery learning berbasis mind mapping dengan siswa yang belajar menggunakan model pembelajaran konvensional, (4) ada interaksi antara model pembelajaran discovery learning berbasis mind mapping terhadap hasil belajar siswa. Berdasarkan hasil penelitian dapat disimpulkan bahwa terdapat pengaruh model pembelajaran discovery learning berbasis mind mapping terhadap hasil belajar siswa.
\end{abstract}

Kata Kunci: discovery learning, mind mapping, hasil belajar

\section{PENDAHULUAN}

Hasil belajar merupakan komponen penting yang tidak dapat dipisahkan dari rangkaian proses belajar mengajar. Hasil belajar berupa perubahan tingkah laku yang membentuk kemampuan manusia meliputi ranah kognitif, afektif dan psikomotor (Bloom, 1978: 7). Hal ini sesuai dengan harapan kegiatan pembelajaran dalam kurikulum 2013 dimana diarahkan untuk memperdayakan semua potensi yang dimiliki peserta didik agar mereka dapat memiliki kompetensi yang diharapkan melalui upaya menumbuhkan serta mengembangkan sikap, pengetahuan dan keterampilan melalui pembelajaran yang menekankan pada pendekatan saintifik (scientific approach).

Kenyataanya, dalam proses pembelajaran fisika masih sering menggunakan metode ceramah, dimana pembelajaran berpusat pada guru yang menyebabkan pembelajaran kurang bermakna (Pramukti, 2013). Hal ini dapat berpengaruh terhadap menurunnya hasil belajar siswa. Oleh karena itu, agar pembelajaran lebih bermakna atau dapat meningkatkan hasil belajar siswa, Bruner (1996) dalam (Dahar, 2010) menyarankan agar peserta didik belajar melalui keterlibatannya secara aktif dengan konsep-konsep dan prinsip yang dapat menambah pengalaman dan mengarah pada kegiatan eksperimen atau guru harus memiliki strategi khusus dalam memilih model pembelajaran yang mengarah pada kegiatan siswa untuk mengamati, menanya, mengolah, menyajikan dan mencipta sehingga proses pembelajaran dapat melibatkan siswa untuk menemukan sendiri konsep yang dipelajari. Model pembelajaran yang mengarah pada penemuan siswa yaitu discovery learning.

Model pembeajaran discovery learning merupakan suatu model pembelajaran dimana siswa membangun pengetahuan mereka sendiri dengan mengadakan suatu pecobaan dan 
menemukan sebuah prinsip dari hasil pecobaan tersebut (Rohim, 2012:2). Kegiatan penemuan yang secara aktif akan memberikan hasil yang paling baik, serta akan lebih bermakna bagi siswa (Bruner dalam Sujana, 2014). Penerapan model pembelajaran penemuan dapat membantu siswa untuk memperbaiki dan meningkatkan keterampilan dan proses kognitif (Ilahi, 2012).

Penerapan model pembelajaran discovery learning memiliki kelemahan yaitu bagi siswa yang memiliki kompetensi rendah akan mengalami kesulitan dalam memahami suatu masalah (Kemendikbut, 2014). Hal ini mengakibatkan hasil belajar siswa menggunakan model pembelajaran discovery tidak merata dan kurang bermakna bagi siswa yang memiliki kemampuan rendah. Untuk mengatasi kelemahan model pembelajaran discovery learning dan agar proses pembelajaran efektif dan efisien dan dapat meningkatkan kreatifitas siswa maka dipadukan dengan mind mapping.

Mind mapping atau peta pikiran merupakan suatu metode pembelajaran yang sangat baik dalam meningkatkan daya hafal siswa dan pemahaman konsep siswa yang kuat serta dapat meningkatkan daya kreatifitasnya melalui kebebasan berimajinasi (Iwan Sugiarto 2004:75). Hal ini didukung oleh peryataan De Porter, Reardon, \& Singer Nourie (2008: 175) metode ini dapat membantu kita mengingat perkataan dan bacaan, meningkatkan pemahaman terhadap materi, membantu mengorganisasikan materi dan memberikan wawasan baru karena di dalamnya memuat kata-kata kunci dalam sebuah topik.

Berdasarkan uraian di atas, dilihat dari peran model pembelajaran discovery learning dan metode mind mapping mengatasi permasalahan dalam pembelajaran fisika untuk menciptakan pembelajaran yang lebih efektif dan efisien sebagai upaya untuk meningkatkan hasil belajar siswa. Focus penelitian ini untuk mengetahui: (1) perbedaan hasil belajar ranah afektif siswa menggunakan model pembelajaran discovery learning berbasis mind mapping dengan siswa yang menggunakan model pembelajaran konvensional, (2) perbedaan hasil belajar ranah kognitif siswa menggunakan model pembelajaran discovery learning berbasis mind mapping dengan siswa yang menggunakan model pembelajaran konvensional, (3) perbedaan hasil belajar ranah psikomotor siswa menggunakan model pembelajaran discovery learning berbasis mind mapping dengan siswa yang menggunakan model pembelajaran konvensional, dan (4) interaksi antara model pembelajaran discovery learning berbasis mind mapping terhadap hasil belajar siswa.

\section{METODE PENELITIAN}

Penelitian ini menggunakan jenis penelitian eksperimen semu (Quasi Experiment) dengan desain posttest only control group design, dengan rancangan analisis penelitian seperti yang ditunjukan pada Tabel 1.

Tabel 1. Matrik Rancangan Analisis Penelitian

\begin{tabular}{|c|c|c|c|}
\hline \multirow{2}{*}{$\begin{array}{l}\text { Variablel } \\
\text { terikat }\end{array}$} & \multicolumn{3}{|c|}{ Hasil Belajar } \\
\hline & $\begin{array}{c}\text { Ranah } \\
\text { Afektif } \\
\left(A_{I}\right)\end{array}$ & $\begin{array}{c}\text { Ranah } \\
\text { Kognitif } \\
\left(A_{2}\right)\end{array}$ & $\begin{array}{c}\text { Ranah Psikomotor } \\
\left(A_{3}\right)\end{array}$ \\
\hline $\begin{array}{c}\text { Discovery Learning-Mind } \\
\text { Mapping }\left(\mathrm{B}_{1}\right)\end{array}$ & $\overline{\mathrm{A}_{1} \mathrm{~B}_{1}}$ & $\mathrm{~A}_{2} \mathrm{~B}_{1}$ & $\mathrm{~A}_{3} \mathrm{~B}_{1}$ \\
\hline Konvensional $\left(\mathrm{B}_{2}\right)$ & $A_{1} B_{2}$ & $\mathrm{~A}_{2} \mathrm{~B}_{2}$ & $A_{3} B_{2}$ \\
\hline
\end{tabular}


Populasi penelitian ini adalah siswa kelas VIII di SMP PGRI 06 Malang tahun ajaran 2018/2019 yang terdiri dari tiga kelas, yaitu VIII A, VIII B, dan VIII C, dengan jumlah 107 siswa. Sampel penelitian yang diambil dari populasi dengan cara purposive sampling, diperoleh kelas VIII A sebagai kelas eksperimen dengan jumlah 35 siswa dan kelas VIII C sebagai kelas kontrol dengan jumlah 35 siswa. Pengukuran kemampuan awal kelas eksperimen dan kelas kontrol menggunakan nilai ulangan harian mata pelajaran fisika dengan menggunakan uji t. Dimana, hasil analisis menunjukan bahwa kemampuan awal siswa kelas eksperimen dan kelas kontrol sama.

Instrumen hasil belajar terdiri dari hasil belajar ranah afektif, hasil belajar ranah psikomotor dan hasil belajar ranah kognitif. Indikator hasil belajar ranah afektif meliputi sikap rasa ingin tahu, sikap kerja sama, sikap jujur dan sikap ketelitian. Indikator hasil belajar ranah psikomotor meliputi keterampilan bertanya, keterampilan mengumpulkan data, keterampilan mengolah data, keterampilan menyimpulkan dan keterampilan mempresentasikan. Hasil belajar ranah kognitif siswa merujuk pada indikator taksonomi Bloon yang digunakan pada penelitian ini yaitu soal mengingat (C1), memahami (C2), mengaplikasi (C3), dan menganalisis (C4). Sebelum instrument digunakan dilakukan validasi 15 butir soal dengan kisaran nilai 0,369 $0,733>0,361$ menunjukan bahwa soal-soal valid digunakan dan uji realibilitas dengan perolehan nilai 0,618 menunjukan reliabilitas tinggi.

Analisis data dilakukan pengujian prasyarat analisis yang meliputi uji normalitas, uji homogenitas dan uji homogenitas varian matrik atau covaria sebagai prasyarat untuk melakukan uji hipotesis penelitian menggunakan uji MANOVA.

\section{HASIL DAN PEMBAHASAN}

Pengujian hipotesis pada penelitian ini dilakukan dengan analisis MANOVA. Pada uji MANOVA akan disajian tabel uji hipotesis untuk melihat perbedaan dan tabel uji hipotesis untuk melihat interaksi. Sebelum data dianalisis dengan analisis MANOVA, sebelumnya dilakukan uji asumsi yang meliputi uji normalitas, uji homogenitas dan uji homogenitas varian matrik atau covaria. Hasil analisis data uji hipotesis disajikan pada Tabel 2 dan 3.

Tabel 2. Tests of Between-Subjects Effects

\begin{tabular}{|c|c|c|c|c|c|c|c|}
\hline \multicolumn{8}{|c|}{ Tests of Between-Subjects Effects } \\
\hline Source & $\begin{array}{c}\text { Dependent } \\
\text { Variable }\end{array}$ & $\begin{array}{l}\text { Type III } \\
\text { Sum of } \\
\text { Squares }\end{array}$ & $\mathrm{df}$ & $\begin{array}{l}\text { Mean } \\
\text { Square }\end{array}$ & $\mathrm{F}$ & Sig. & $\begin{array}{l}\text { Partial } \\
\text { Eta } \\
\text { Squared }\end{array}$ \\
\hline \multirow[t]{3}{*}{ Model_Pemb } & Ranah Afektif & 1277.157 & 1 & 1277.157 & 4.512 & .037 & .062 \\
\hline & Ranah Psikomotor & 788.929 & 1 & 788.929 & 4.317 & .042 & .060 \\
\hline & Ranah Kognitif & 642.057 & 1 & 642.057 & 7.148 & .009 & .095 \\
\hline
\end{tabular}

Tabel 3. Multivariate Tests

\begin{tabular}{|c|c|c|c|c|c|c|c|}
\hline \multicolumn{8}{|c|}{ Multivariate Tests ${ }^{b}$} \\
\hline \multicolumn{2}{|r|}{ Effect } & \multicolumn{5}{|c|}{ Hypothesis } & $\begin{array}{c}\text { Partial Eta } \\
\text { Squared }\end{array}$ \\
\hline \multirow[t]{4}{*}{ Model_Pemb } & Pillai's Trace & .161 & $4.232 \mathrm{a}$ & 3.000 & 66.000 & .008 & .161 \\
\hline & Wilks' Lambda & .839 & $4.232 \mathrm{a}$ & 3.000 & 66.000 & .008 & .161 \\
\hline & Hotelling's Trace & .192 & $4.232 \mathrm{a}$ & 3.000 & 66.000 & .008 & .161 \\
\hline & $\begin{array}{l}\text { Roy's Largest } \\
\text { Root }\end{array}$ & .194 & $4.232 \mathrm{a}$ & 3.000 & 66.000 & .008 & .161 \\
\hline
\end{tabular}


Berdasarkan Tabel 2 dapat disimpulkan bahwa hasil uji hipotesis menunjukan bahwa nilai sig. $\left\langle 0,05\right.$ dan nilai $F_{\text {hitung }}>F_{\text {tabel }}$. Dimana, nilai $F_{\text {tabel }}=3,134$. Hal ini dapat disimpulkan bahwa ada perbedaan hasil belajar ranah afektif, hasil belajar ranah psikomotor dan hasil belajar ranah kognitif siswa yang belajar menggunakan model pembelajaran discovery learning berbasis mind mapping dengan siswa yang balajar menggunakan model pembelajaran konvensional. Berdasarkan Tabel 3 menunjukan bahwa nilai sig. Hotelling's Trace lebih kecil dari 0,05 (0,008 $<0,05)$. Hal ini menunjukan bahwa ada interaksi model pembelajaran discovery learning berbasis mind mapping terhadap hasil belajar siswa.

\section{Hasil Belajar Ranah Afektif}

Hasil analisis hipotesis menunjukan bahwa ada perbedaan hasil belajar ranah afektif antara siswa yang belajar menggunakan model pembelajaran discovery learning berbasis mind mapping dengan siawa yang belajar menggunakan model pembelajaran konvensional. Hal ini dapat dilihat dari Gambar 1.

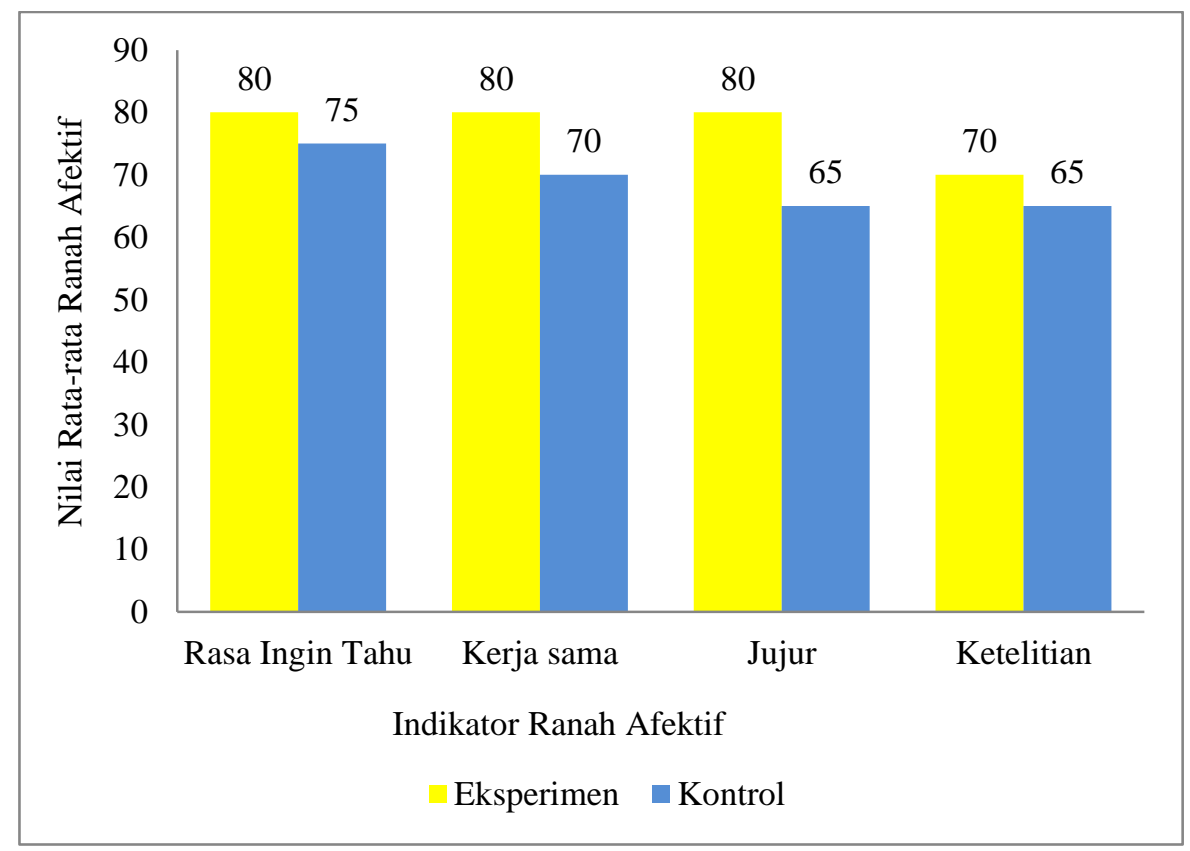

\section{Gambar 1. Diagram Perbandingan Nilai Rata-rata Per Indikator Hasil Belajar Ranah Afektif}

Hasil penelitian ini didukung oleh beberapa penelitian sebelumnya yang dilakukan oleh Mubarok (2014) menyatakan bahwa hasil belajar siswa kelas eksperimen dengan menggunakan model pembelajaran discovery larning lebih baik jika dibandingkan dengan kelas kontrol. Hasil penelitian Faelasori, dkk (2015: 135) mengemukakan bahwa mind mapping yang dilakukan banyak memberikan kesempatan kepada siswa untuk dapat lebih aktif dan siswa menjadi lebih termotivasi dalam proses pembelajaran yang memancin siswa lebih imajinatif serta kreaif dalam mengembangkan potensi kerja otak dan pola pikirnya sehinga siswa dapat berpikir aktif, kritis, penuh ide dan mudah mengantur segala bentuk informasi yang disampaikan oleh guru". Sari, E.N.,dkk (2016) menyatakan bahwa model pembelajaran discovery learning dengan mind mapping berpengaruh pada hasil belajar kognitif, afektif dan psiomotor siswa.

Perbedaan nilai per indikator hasil belajar ranah afektif antara kelas eksperimen dan kelas kontrol dapat dilihat dari penggunaan model dan metode yang diterapkan selama proses pembelajaran. Nilai rata-rata setiap indikator hasil belajar ranah afektif pada kelas eksperimen dengan model pembelajaran discovery learning berbasis mind mapping lebih tinggi dibandingkan dengan nilai rata-rata per indikator hasil belajar ranah afektif dengan model pembelajaran konvensional.

Penerapan model pembelajaran discovery learning berbasis mind mapping yang diterapkan pada kelas eksperimen dimulai dengan tahap pertama yaitu stimulation (pemberian 
ransangan/stimulasi). Pada tahap ini guru menunjukan gambar penerapan materi tekanan dalam kehidupan sehari-hari. Pemberian stimulus bertujuan untuk membangkitkan rasa ingin tahu siswa untuk menemukan dan menyelidiki sendiri permasalahan dan meransang peserta didik untuk terlibat aktif mengikuti kegiatan pembelajaran. Dimana, menurut McElmeel (2002: 51) rasa ingin tahu adalah keinginan untuk belajar, menyelidiki atau mengetahui. Oleh karena itu, hal ini perlu diperhatikan karena sikap rasa ingin tahu menjadi faktor yang sangat penting untuk menggerakkan motivasi dan minat yang tinggi bagi siswa untuk belajar. Seperti yang dikemukakan oleh Irma (2008), bahwa siswa termotivasi dalam belajar yang dilakukan guru dengan pembelajaran yang menciptakan suasana hidup, siswa menjadi percaya diri dan berusaha memperoleh nilai yang baik, memiliki semangat atau gaira dalam belajar. Tahap lain yang mendukung peningkatan indikator rasa ingin tahu siswa yaitu problem statement (peryataan/identifikasi masalah). Pada tahap ini guru mengarahkan siswa untuk memberikan pertanyaan-pertanyaan sesuai dengan permasalahan pada gambar. Kegiatan ini membantu mengoptimalkan rasa sikap ingin tahu dalam bertanya atau menanggapi permasalahan dan juga membantu siswa menemukan permasalahan dan cara mengatasinya. Dengan demikian, hasil belajar ranah afektif rasa ingin tahu siswa pada kelas eksperirmen dapat dilaksanakan dengan baik. Sedangkan pada kelas kontrol dengan model pembelajaran konvensional dapat dilihat bahwa perbedaan selisi nilai rata-rata sikap rasa ingin tahu kelas eksperimen dengan model pembelajaran discovery learning berbasis mind mapping tidak jauh berbeda. Hal ini terjadi karena pada kelas kontrol menggunakan metode praktikum. Dimana, kegiatan praktikum dapat mendorong siswa untuk aktif dalam kegiatan pembelajaran tetapi karena pada pembelajaran dengan model konvensional kegiatan yang dilakukan pada awal kegiatan yaitu guru menyampaikan pokok bahasan kemudian menyampaikan tujuan pembelajaran dan diarahkan untuk melakukan praktikum. Hal ini tentunya tidak begitu menarik simpati siswa karena tidak diberikan stimulus untuk membangkitkan rasa ingin tahu siswa sebagai modal awal untuk menggerakan siswa pada kegiatan pembelajaran selanjutnya atau dalam melakukan praktikum. Kondisi inilah yang menyebabkan nilai rata-rata kelas kontrol lebih kecil dibandingkan dengan kelas eksperimen.

Kegiatan yang mendukung peningkatan indikator sikap kerja sama siswa pada kelas eksperimen yaitu pada tahap ketiga model pembelajaran discovery learning berbasis mind mapping yaitu data collection (pengumpulan data). Pada tahap ini siswa mengumpulkan data melalui kegiatan praktikum untuk menjawab atau menemukan solusi dari permasalahan. Penerapan fase ini dilakukan dengan mengorganisasikan siswa dalam melakukan praktikum. Pengorganisasian ini dilakukan mengingat dalam proses pengelompokan terjadi diskusi kelompok yang yang dapat menciptakan interaksi antara dua orang atau lebih individu saling bertukar penalaman atau informasi (Roestiyah, 2008). Pengorganisasian juga bertujuan untuk menumbukan sikap kerja sama siswa. dimana, menurut Rukiyati, dkk (2014) menekankan bahwa karakter kerja sama dapat menumbuhkan tingkat percaya diri dengan harapan siswa mudah beradaptasi dengan teman kelompok baru. Dengan demikian, pada kelas eksperimen sikap kerja sama siswa dapat dalam melakukan praktikum dapat dilaksanakan dengan baik dan lancar. Sedangkan pada kelas kontrol dengan model pembelajaran konvensional, siswa kurang menunjukan sikap kerja samanya dalam melaksanakan kegiatan praktikum. Hal ini dikarenakan pada kelas kontrol dengan model pembelajaran konvensional siswa langsung diarahkan untuk melakukan praktikum tanpa diberikan stimulus yang dapat membangkitkan minat atau rasa ingin tahu siswa dalam melasanakan praktikum. Kondisi demikian menyebabkan kurangnya sikap kerja sama siswa dalam kelompok dalam melakukan praktikum atau kegiatan pembelajaran selanjutnya.

Indikator lain yang diperhatikan pada hasil belajar ranah afektif yaitu sikap jujur. Sikap ini dapat dilihat secara lansung selama proses pembelajaran di kelas. Jika siswa menyontek atau memperhatikan pekerjaan kelompok lain, hal ini merupakan perbuatan yang mencerminkan anak atau siswa tidak berbuat jujur kepada diri, teman, orang tua, dan gurunya. Hal ini didukung oleh peryataan (Lickona, 1992) bahwa sebagai karakter yang baik, yaitu moral knowing, moral feeling dan moral action. Bagaimana kita berpikir secara jujur untuk menyampaikan data, bersikap jujur untuk mengatakan apa adanya dan berperilaku jujur dalam mengungkapkan data. Pada penelitian ini untuk mengukur sikap jujur siswa kegiatan yang harus diperhatikan pada 
kelas ekspeimen dengan model pembelajaran discovery learning berbasis mind mapping yaitu pada kegiatan pengumpulan data (data collection), pengolahan data (data processing) dan melaporkan atau mempresentasikan hasil diskusi. Dari ketiga kegiatan ini diperhatikan apakah siswa melakukan kegiatan ini berdasarkan hasil eksperimen. Didukung oleh sikap rasa ingin tahu dan sikap kerja sama yang dapat memotivasi dan dapat menumbukan rasa percaya diri dalam melaksanakan kegiatan-kegiatan ini, pada kelas eksperimen hasil belajar ranah afektif sikap jujur siswa dapat dilaksanakan dengan baik. Kondisi ini. Sedangkan pada kelas kontrol dengan model pembelajaran konvensional kegiatan pengumpulan data (data collection), pengolahan data (data processing) dan melaporkan atau mempresentasikan hasil diskusi kurang optimal dilaksanakan. Kondisi ini dikarenakan kurangnya sikap rasa ingin tahu dan sikap kerja sama yang berdampak terhadap hasil belajar ranah afektif sikap jujur atau kurang percaya diri siswa kurang optimal dilaksanakan.

Mengukur indikator ketelitian pada hasil belajar ranah afektif yaitu dengan mengamati bagaimana siswa melakukan pengukuran dengan teliti dan waktu yang dibutuhkan dalam melakukan kegiatan ini. Pengukuran indikator ini yang paling penting, pengukuran indikator ketelitian (conscientiousness) dalam suatu bidang dapat memprediksi prestasi kerja seseorang dan bermacam-macam prilaku yang akan datang (Schmidt et al dalam Goldberg, et. al. (2005)). Oleh karena itu, perlunya tahapan atau kegiatan yang mendukung pengukuran indikator ini. Pada model pembelajaran discovery learning berbasis mind mapping tahap yang mendukung kegiatan pengukuran indikator ini yaitu pada tahap pengumpulan data (data collection). Untuk mengoptimalkan sikap ketelitian siswa dapat juga dilihat pada kegiatan verification (pembuktian). Dimana, dilakukan pemeriksaan secara cermat data yang diperoleh sehingga memperoleh hasil yang lebih akurat yang dapat menjawab permasalahan. Hal ini didukung oleh atusias siswa dan sikap kerja sama dalam melakukan kegiatan praktikum sehingga indikator hasil belajar ranah afektif sikap ketelitian siswa dapat dilakanakan dengan baik. Sedangkan pada kelas kontrol dengan model konvensional kurangnya sikap ketelitian siswa. Dimana, untuk mengukur indikator ketelitian dilakukan pada kegiatan pengumpulan data (data collection). Berdasarkan penilaian terhadap indikator sikap ketelitian menunjukan bahwa siswa kurang teliti dan waktu yang diperlukan siswa dalam melakukan kegiata ini membutukan waktu yang banyak. Kondisi ini dikarenakan kurangnya antusias dan sikap kerja sama siswa. Dengan demikian, mengakibatkan kurang maksimalnya hasil belajar ranah afektif sikap ketelitian siswa.

Selanjutnya untuk mendukung kegiatan pembelajaran pada kelas eksperimen dengan model pembelajaran discovery learning maka, dibantu dengan metode mind mapping. Metode ini diterapkan setelah siswa menemukan kesimpulan akhir dari materi yang disampaikan. Penggunaan metode ini membantu siswa yang memiliki kemampuan rendah dalam memahami permasalahan yang disampaikan. Selain itu, metode ini juga melatih siswa dalam bekerja sama dan lebih kreatif dalam berpikir.

Berdasarkan penjelasan perbandingan tiap indikator untuk kelas eksperimen dengan model pembelajaran discovery learning berbasis mind mapping dan kelas kontrol dengan model pembelajaran konvensional maka dapat disimpulkan bahwa ada perbedaan hasil belajar ranah afektif siswa kelas eksperimen dengan model pembelajaran discovery learning berbasis mind mapping lebih efektif dalam meningkatkan hasil belajar ranah afektif siswa dibandingkan dengan kelas kontrol dengan model pembelajaran konvensional.

\section{Hasil Belajar Ranah Psikomotor}

Hasil analisis hipotesis pada menunjukan bahwa ada perbedaan hasil belajar ranah psikomotor antara siswa yang belajar menggunakan model pembelajaran discovery learning berbasis mind mapping dengan siawa yang belajar menggunakan model pembelajaran konvensional. Hal ini dapat dilihat pada Gambar 2. 


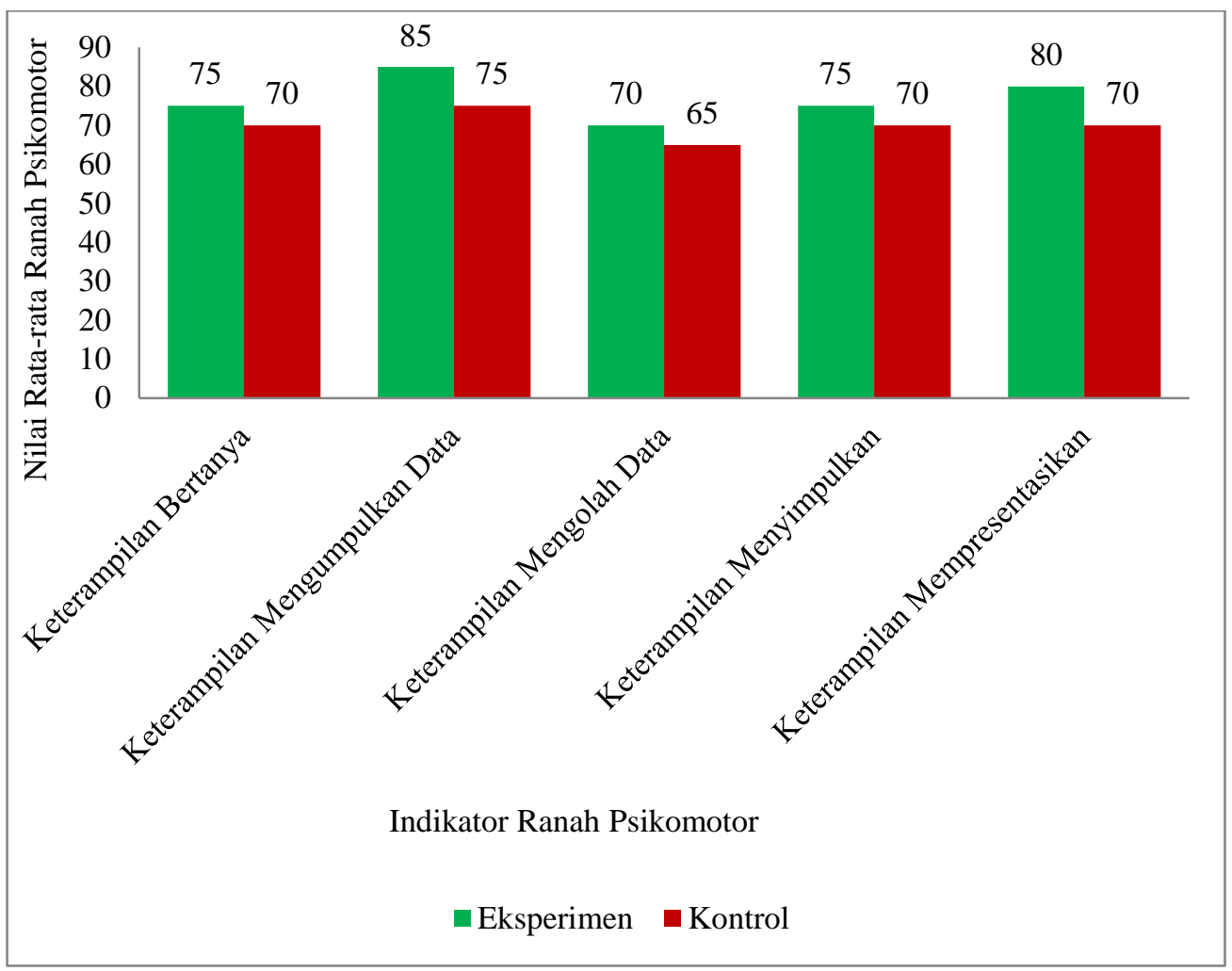

Gambar 2. Diagram Perbandingan Nilai Rata-rata Per Indikator Hasil Belajar Ranah Psikomotor

Hasil penelitian ini didukung oleh beberapa penelitian sebelumnya yang dilakukan oleh Qomariyah (2014) bahwa model pembelajaran discovery larning berpengaruh terhadap keterampilan proses sains siswa, penelitian yang dilakukan oleh Ulumi et al, (2015) yang menyimpulkan bahwa model pembelajaran guided discovery learning berpengaruh terhadap hasil belajar siswa baik kognitif, afektif maupun psikomotor, penelitian Susanti (2015) dengan judul menunjukan bahwa penerapan LKPD berbasis discovery learning berbantuan mind mapping memberikan pengaruh yang berarti terhadap kompetensi IPA siswa. Kompetensi IPA siswa ditinjauh berdasarkan hasil belajar dan keterampilan dan penelitian Liu et al, (2014) menyimpulkan bahwa penggunaan mind mapping dalam pembelajaran berpengaruh terhadap hasil belajar siswa.

Perbedaan nilai rata-rata per indikator hasil belajar ranah psikomotor antara kelas eksperimen dan kelas kontrol ini dapat dilihat dari penggunaan model dan metode yang diterapkan selama proses pembelajaran. Nilai rata-rata setiap indikator hasil belajar ranah psikomotor pada kelas eksperimen dengan model pembelajaran discovery learning berbasis mind mapping lebih tinggi dibandingkan dengan nilai rata-rata per indikator hasil belajar ranah psikomotor dengan model pembelajaran konvensional.

Pengukuran keterampilan bertanya perlu dilakukan mengingat kegiatan perumusan pertanyaan-pertanyaan merupakan salah satu bagian yang paling penting dan paling kreatif dari sains yang diabaikan dalam pendidikan sains (Piaget dalam Dahar, 1998). Oleh karena itu, perlu dilakukan pengukuran keterampilan bertanya. Pada kelas eksperimen menggunakan model pembelajaran discovery learning berbasis mind mapping. Penerapan model dan metode ini dimulai dengan tahap pertama yaitu stimulation (pemberian ransangan/stimulasi). Kegiatan yang dilakukan pada tahap ini guru menunjukan gambar penerapan materi tekanan dalam kehidupan sehari-hari. Pemberian stimulasi/ransangan bertujuan agar siswa dapat menemukan permasalahan atau dapat merumuskan permasalahannya sendiri dan meransang peserta didik untuk terlibat aktif mengikuti kegiatan pembelajaran. Kegiatan ini dapat meningkatkan indikator keterampilan bertanya. Untuk mengoptimalkan keterampilan bertanya dapat dilakukan melalui tahap kedua model pembelajaran discovery learning berbasis mind mapping yaitu problem statement (peryataan/identifikasi masalah). Pada tahap ini kegiatan yang dilakukan guru adalah 
mengarahkan siswa untuk memberikan pertanyaan-pertanyaan sesuai dengan permasalahan pada gambar. Dengan demikian, kegiatan ini membantu mengoptimalkan keterampilan siswa dalam bertanya. Berbeda dengan kelas eksperimen, penerapan model pembelajaran konvensional dimulai dengan guru menyampaikan pokok bahasan kemudian menyampaikan tujuan pembelajaran dan lansung diarahkan untuk melakukan kegiatan praktikum. Hal ini tentunya tidak begitu menarik simpati siswa untuk mengemukakan ide atau gagasan berkaitan dengan permasalahan yang mereka temukan karena tidak diberikan stimulus. Kondisi ini menyebabkan kurang optimalnya keterampilan siswa dalam bertanya.

Indikator keterampilan mengumpulkan data dapat dilihat pada kegiatan pengumpulan data (data collection). Pada tahap ini siswa terlihat antusias dan aktif dalam melakukan kegiatan mengumpulkan data seta siswa diberi kesempatan mengenali hubungan inferensial yang diharapkan antara peryataan dan deskripsi teori dengan kenyataan yang terjadi berdasarkan pengalaman (Haris, dkk., 2015). Adapun hal yang harus diperhatikan pada saat melakukan penilaian terhadap indikator ini yaitu keterampilan siswa dalam menggunakan alat dan bahan serta keterampilan siswa dalam melaksanakan pratikum secara tepat dan cepat. Dimana, kegiatan ini dilakukan dengan mengorganisasikan siswa untuk bekerja sama dalam kelompok. Pada kelas eksperimen dengan model pembelajaran discovery learning berbasis mind mapping indikator ini dapat dilakukan dengan baik. Kondisi ini didukung oleh keatifan dan kerja sama siswa. Sedangkan pada kelas kontrol dengan model pembelajaran konvensional, keterampilan siswa dalam mengumpulkan data atau keterampilan siswa dalam menggunakan alat dan bahan serta melaksanakan praktikum kurang optimal dilaksanakan. Hal ini dikarenakan kegiatan awal yang kurang meransang keterlibatan atau kerja sama siswa dalam melakukan praktikum sehingga berpengaruh terhadap keterampilan siswa dalam mengumpulkan data.

Tahap keempat model pembelajaran discovery learning berbasis mind mapping pada kelas eksperimen yaitu data processing (pengolahan data). Pada tahap ini dapat mengukur indikator keterampilan siswa dalam mengolah data dan menganalisis informasi yang diperoleh dari pengumpulan data yang akan menjawab permasalahan. Hal ini didukung oleh pendapat (Melani, dkk., 2012), bahwa pada tahap data collection dan tahap data processing dapat melati siswa untuk menggunakan metode ilmiah dalam menyelesaikan masalah, sehingga tidak mudah percaya pada sesuatu yang belum pasti kebenarannya. Bagaimana siswa memperoleh data hasil percobaan dan menjawab pertanyaan pada lembar kerja siswa (LKS) dengan tepat. Selain itu, untuk memaksimalkan proses pengolahan data pada kelas eksperimen dengan model pembelajaran discovery learning berbasis mind mapping maka, dilakukan verification (pembuktian) sehingga data yang diperoleh lebih akurat atau memperoleh tingkat kesesuian tinggi. Dimana pada tahap ini, dilakukan pemeriksaan secara cermat data yang diperoleh sehingga dapat menjawab permasalahan. Hal ini juga didukung dari hasil penelitian (Widiadnyana, dkk., 2014) mengatakan bahwa kegiatan ini dapat memunculkan sikap kritis, kemauan mengubah pandangan terhadap jawaban karena terungkap bukti-bukti dari informasi yang telah dipelajari sehingga siswa akan memperoleh pemahaman suatu konsep yang telah dipelajari. Kondisi ini memperlihatkan pada kelas eksperimen keterampilan siswa dalam mengolah data dapat dilakukan dengan baik. Sedangkan keterampilan mengolah data pada kelas kontrol dengan model pembelajaran konvensional kurang akurat atau tingkat kesesuaian rendah. Kondisi ini dikarenakan kurangnya partisipasi atau kerja sama siswa dalam melaksanakan praktikum yang menyebabkan kurangnya pemahaman siswa dalam memecahkan permasalahan. Dengan demikian, mempengaruhi keterampilan siswa dalam mengolah data.

Upaya selanjutnya untuk memaksimalkan hasil belajar ranah psikomotor yaitu kegiatan penarikan kesimpulan. Tahap ini mendukung penilaian keterampilan menyimpulkan. Pada tahap ini dilakukan penilaian terhadap keterampilan siswa dalam membuat kesimpulan dengan jelas dan tepat waktu. Dimana, keterampilan menyimpulkan merupakan aspek penting dari keterampilan proses sains karena keterampilan ini menuju pada pembuatan kesimpulan mengenai hasil observasi yang didasarkan atas pengetahuan siswa (Indrawati, 1999). Dengan kata lain, kesimpulan ini merupakan suatu konsep atau solusi dari permasalahan yang dapat dijadikan sebagai prinsip umum. Kondisi ini dikarenakan pada kelas eksperimen setiap tahapannya dilakukan denga baik sehingga kegiatan penarikan kesimpulan dapat dilaksanakan dengan lancar. Sedangkan pada kelas kontrol dengan model pembelajaran konvensional, 
keterampilan siswa dalam menyimpulkan kurang maksimal dilaksanakan. Adapun penyebabnya yaitu pada kelas kontrol setiap tahapan dari proses pembelajaran konvensional kurang mendukung keterampilan siswa dalam menyimpulkan.

Indikator selanjutnya yang diamati yaitu keterampilan mempresentasikan atau mengkomunikasikan. Menurut Nasution (2007) keterampilan mengkomunikasikan dapat dikembangkan dengan menghimpun informasi dari grafik atau gambar yang menjelaskan bendabenda serta kejadian-kejadian secara rinci. Pada tahap ini, setelah siswa menemukan kesimpulan dan menjawab pertanyaan-pertanyaan pada lembar kerja siswa (LKS), selanjutnya siswa mempresentasikan atau mengkomunikasikan hasil diskusi. Penilaian keterampilan mempresentasikan ini melihat bagaimana siswa menyampaikan hasil diskusi, mempertahankan dan menanggapi pertanyaan dengan baik. Pada kelas eksperimen dengan model pembelajaran discovery learning berbasis mind mapping siswa dapat mempresentasikan hasil diskusinya dengan baik. Hal ini didukung oleh rasa percaya diri siswa pada kelas eksperimen yang berperan aktif dan bekerja sama dalam melakukan praktikum. Sedangkan pada kelas kontol keterampilan siswa dalam mempresentasikan atau menyampaikan hasil diskusi dan mempertahankan serta menggapi pertanyaan kurang optimal. Hal ini terjadi karena pada kelas kontrol siswa kurang tertarik atau kurangnya kerja sama dalam melakukan praktikum yang mengakibatkan kurangnya rasa percaya diri dan kurangnya pemahaman terhadap materi atau permasalahannya.

Selanjutnya untuk mendukung kegiatan pembelajaran pada kelas eksperimen dengan model pembelajaran discovery learning maka, dibantu dengan metode mind mapping. Metode ini diterapkan setelah siswa menemukan kesimpulan akhir dari materi yang disampaikan. Penggunaan metode ini membantu siswa yang memiliki kemampuan rendah dalam memahami permasalahan yang disampaikan. Selain itu, metode ini dapat meningkatkan nilai-nilai keterampilan lain siswa yang berusaha untuk lebih memahami materi pembelajaran.

Berdasarkan penjelasan perbandingan tiap indikator untuk kelas eksperimen dengan model pembelajaran discovery learning berbasis mind mapping dan kelas kontrol dengan model pembelajaran konvesional maka dapat disimpulkan bahwa ada perbedaan hasil belajar ranah psikomotor siswa. Kelas eksperimen dengan model pembelajaran discovery learning berbasis mind mapping lebih efektif dalam meningkatkan hasil belajar ranah psikomotor siswa dibandingkan dengan kelas kontrol dengan model pembelajaran konvensional.

\section{Hasil Belajar Ranah Kognitif}

Hasil analisis hipotesis menunjukan bahwa ada perbedaan hasil belajar ranah kognitif antara siswa yang belajar menggunakan model pembelajaran discovery learning berbasis mind mapping dengan siawa yang belajar menggunakan model pembelajaran konvensional. Berdasarkan hasil analisis jelas bahwa penerapan model pembelajaran discovery learning berbasis mind mapping berpengaruh terhadap hasil belajar ranah kognitif. Hasil penelitian ini didukung oleh beberapa penelitian terdahulu yang menunjukan hasil yang sama. Diantaranya penelitian yang dilakukan oleh Utami (2017) menyatakan bahwa model pembelajara discovery learning daat meningkatkan keterampian berpikir kritis dan pemahaan konsep, Nuryandari (2017) menyatakan bahwa metode mind mapping berpengaruh terhadap pemahaman konsep dan penelitian Long \& Carlson (2011) menyimpulkan bahwa penggunaan mind mapping dalam pembelajaran mampu meningkatkan kemampuan berpikir kritis siswa dan mampu membentuk konsep pengetahuan siswa.

Adapun perbadingan nilai hasil belajar ranah kognitif siswa yang dianalisis menunjukan bahwa adanya perbedaan nilai hasil belajar ranah kognitif selama proses pembelajaran berlansung. Perbedaan ini dapat dilihat dari penggunaan model dan metode yang diterapkan selama proses pembelajaran. Nilai rata-rata hasil belajar ranah kognitif pada kelas eksperimen dengan model pembelajaran discovery learning berbasis mind mapping lebih tinggi dibandingkan dengan nilai rata-rata hasil belajar ranah kognitif dengan model pembelajaran konvensional. Hal ini dapat dilihat pada Gambar 3. 


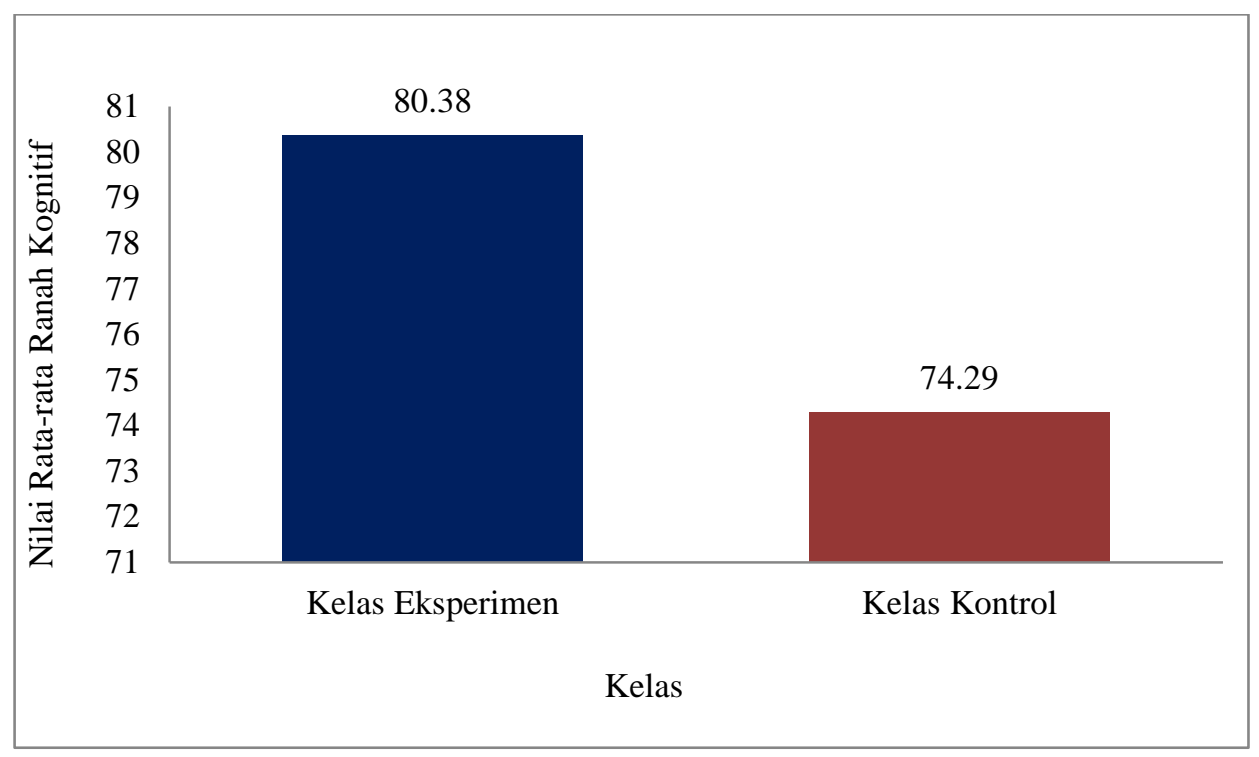

Gambar 3. Diagram Perbandingan Nilai Rata-rata Hasil Belajar Ranah Kognitif

Tahapan-tahapan model pembelajaran discovery learning berbasismind mapping dimulai dari stimulation (stimulasi/pemberian rangsangan), problem statement (peryataan/identifikasi masalah), data collection (pengumpulan data), data processing (pengolahan data), verification (pembuktian), generalization (generalisasi/menarik kesimpulan) dan penyusunan mind mapping. Kegiatan-kegiatan yang dilakukan pada setiap tahapan diupayakan mampu mempengaruhi siswa untuk terlibat aktif dalam proses pembelajaran. Hal ini bertujuan agar siswa mampu menemukan suatu masalah dari permasalahannya dalam kehidupan sehari-hari dan juga bagaimana siswa menemukan suatu konsep sebagai solusi dari permasalahan tersebut. Dalam proses pembelajaran ini juga perluhnya suatu metode (mind mapping) sebagai suatu cara untuk mengatasi permasalahan dari model permbelajaran (discovery learning) yang digunakan dalam proses pembelajaran sehingga siswa yang memiliki kemampuan rendah dapat memahami permasalahan yang disampaikan. Dengan demikian, penerapan model pembelajaran discovery learning berbasis mind mapping bisa berpengaruh terhadap pemahaman konsep atau hasil belajar ranah kognitif siswa. Dimana, Pemahaman konsep dapat diartikan sebagai proses berpikir seseorang untuk mengolah bahan belajar yang diterima sehingga menjadi bermakna (Aunurrahman, 2012: 54).

Pada kelas kontrol dengan model pembelajaran konvensional, kegiatan awal pembelajaran kurang memotivasi siswa untuk terlibat aktif dalam pembelajaran. Hal ini berpengaruh terhadap kegiatan pembelajaran selanjutnya. Kondisi ini mempengaruhi kurangnya pemahaman konsep atau hasil belajar ranah kognitif siswa terhadap materi yang disampaikan.

\section{Interaksi Antara Model Pembelajaran Discovery Learning Berbasis Mind Mapping Terhadap Hasil Belajar Siswa}

Hasil analisis hipotesis menunjukan bahwa ada pengaruh interaksi antara model pembelajaran discovery learning berbasis mind mapping terhadap hasil belajar (ranah afektif, ranah psikomotor, dan ranah kognitif) siswa. Pengambilan keputusan ini berdasarkan hasil analisis menggunakan SPSS dengan uji MANOVA, dimana nilai sig. Hotelling's Trace < 0,05 $(0,008<0,05)$. Hal ini menunjukan bahwa ada interaksi antara model pembelajaran discovery learning berbasis mind mapping terhadap hasil belajar siswa.

Menurut Muhammad Ali (1995:112) bahwa keseluruhan komponen-komponen saling berinteraksi dan berhubungan bersama diarahkan untuk mencapai tujuan. Hal ini dapat dilihat dari penerapan model pembelajaran discovery learning berbasis mind mapping tidak hanya berpengaruh terhadap masing-masing variabel tetapi penerapan model pembelajaran discovery learning berbasis mind mapping memiliki interaksi terhadap variabel hasil belajar ranah afektif, hasil belajar ranah psikomotor dan hasil belajar rana kognitif. Discovery learning berbasis mind 
mapping merupakan suatu model pembelajaran penemuan dimana siswa mampu menemukan atau merumuskan dan menyelidiki sendiri permasalahannya secara sistematis sehingga siswa dapat menemukan suatu konsep yang dijadikan sebagai solusi dari permasalahan dan mind mapping sebagai suatu metode untuk mengoptimalkan kelemahan dari model pembelajaran ini.

Penerapan model pembelajaran discovery learning berbasis mind mapping memiliki keterkaitan terhadap pengembangan hasil belajar ranah afektif siswa. Penerapan model dan metode yang sudah diorganisir sedemikian rupa akan membantu menumbuhkan sikap siswa yang menjadi faktor penting dalam memotivasi siswa agar aktif dalam proses pembelajaran atau bagaimana siswa aktif menunjukan keterampilan prosesnya dalam melakukan pengumpulan data dan melakukan penyusunan mind mapping yang bertujuan agar semua siswa memahami permasalahan yang disampaikan. Dengan demikian, dapat mempengaruhi pemahaman konsep siswa atau hasil belajar ranah kognitif. Dengan penerapan model pembelajaran discovery learning berbasis mind mapping dan pengorganisasian setiap tahapan yang dilakukan secara maksimal maka, akan berpengaruh terhadap hasil belajar ranah afektif dan hasil belajar ranah psikomotor sehingga dapat meningkatkan hasil belajar ranah kognitif siswa. Dengan kata lain, adanya interaksi antara model pembelajaran discovery learning berbasis mind mapping terhadap hasil belajar siswa seperti hasil penelitian ini.

\section{PENUTUP}

Berdasarkan data hasil analisis dari penelitian yang telah dilaksanakan, dapat disimpulkan bahwa terdapat pengaruh model pembelajaran discovery learning berbasis mind mapping terhadap hasil belajar siswa.

Saran bagi peneliti selanjunya, dalam proses pembelajaran menggunakan model pembelajaran discovery learning berbasis mind mapping, pada kegiatan awal atau saat memberikan stimus diharapkan untuk menggunakan video sehingga siswa dengan mudah menemukan masalah dan dapat mengaitkan dengan permasalahannya dalam kehidupan seharihari.

\section{DAFTAR PUSTAKA}

Ali, M. (1995). Proses Belajar Mengajar. Bandung: Sinar Baru.

Aunurrahman. (2012). Belajar dan Pembelajaran. Bandung: Alfabeta.

Bloom, Benjamin S, Max D. Engelhart, Edwart J. Forst, Walker H. Hill, dan David R. Krathwohl. 1978. Taxonomy of Educational Objective: The Classification of Educational Goals, Handbook 1: Cognitive Domain. New York: David McKay Company.

Bobbi D.P, Mark R, \& Sarah S.N. 2008. Quantum Teaching: Mempraktikan Quantum Learning Di Ruang Kelas. Bandung: Kaifa.

Dahar, Ratna Wilis. 1998. Teori-teori Belajar . Jakarta: Proyek Pengembangan LPTK.

Dahar, R. W. 2010. Teori-teori Belajar dan Pembelajaran. Jakarta: Erlangga.

Faelasofi, dkk. 2015. Metode Pembelajaran Mind Mapping Untuk Meningkatkan Kemampuan Komunikasi Matematika Siswa Dalam Pemecahan Masalah Matematika. Jurnal e-Dumath, 1(2), 122-136.

Goldberg, L. R., Roberts, B. W., Chernyshenko, O. S., Stark, S. 2005. The Structure of Conscientiousness: an Empirical Investigation Based on Seven Major Personality Questionnaires. Journal of Personnel Psychology. Vol 58.

Haris, Fuad, Yudi R., Umi F. 2015. Pengaruh Model Guided Discovery Learning terhadap Kemampuan Berpikir Kritis Siswa Kelas X SMA Negeri 
Karangpandan Tahun Pelajaran 2013/2014. Jurnal pendidikan Biologi. 7(2): 114-122.

Ilahi, T M. 2012. Pembelajaran Discovery Strategy \& Mental Vocational Skill. Jogjakarta: DIVA Press

Indrawati. 1999. Keterampilan Proses Sains (KPS). Bandung: Pusat Pengembangan Penataran Guru Ilmu Pengetahuan Alam.

Irma Pujiati. 2008. Peningkatan Motivasi Dan Ketuntasan Belajar Melalui Pembelajaran Kooperatif Tipe Stad. Jurnal Ilmiah Kependidikan, 1(1) (September 2008), 1-20.

Kemendikbud, 2014. Model Pembelajaran Penemuan (Discovery Learning). Jakarta : Badan Pengembangan SDM Pendidikan dan Kebudayaan dan Penjaminan Mutu Pendidikan.

Lickona, T. 1992. Educating for Character. New York: Bantam Books.

Liu, Y., Zhao, G., Ma, G., \& Bo, Y. (2014). The Effect of Mind Mapping on Teaching and Learning: a Meta-Analysis. Standard Journal of Education and Essay, 2(1), 017-031.

Long, D. J., \& Carlson, D. (2011). Mind the Map: How Thinking Maps Affect Student Achievement. Networks: An Online Journal for Teacher Research, 13(2), 262262.

McElmeel, S. L. 2002. Character Education: A Book Guide for Teachers, Librarians and Parents. Colurado: Greenwood Publishing Group, Inc.

Melani, Riyan, Harlita, dan Bowo Sugiharto. 2012. Pengaruh Metode Guided Discovery Learning terhadap Sikap Ilmiah dan Kemampuan Kognitif Biologi Siswa SMA Negeri 7 Surakarta Tahun Pelajaran 2011/2012. Jurnal Pendidikan Biologi. 4(1): 97-105.

Mubarok, C. 2014. Penerapan Model Pembeajaran Discovery Learning Terhadap Hasil Belajar Siswa Kelas X Tav Pada Standar Kompetensi Melakukan Instalasi Sound System Di SMK Negeri 2 Surabaya. Jurnal Pendidikan Teknik Elektro, 3 (1), 215-121.

Nasution, N, dkk. 2007. Pendidikan IPA di SD. Universitas Terbuka: Jakarta.

Nuryandari. 2017. Pengaruh Metode Mind Mapping Untuk Meningkatkan Pemahaman Konsep dan Sikap Dalam Pembelajaran Matematika Kelas VIII SMP Negeri 2 Sentolo. Skripsi tidak diterbitkan. Yogyakarta: Universitas Mercu Buana.

Pramukti, S.H. 2013. Komparasi Pengaruh Pengunaan Metode Ceramah dan Team Game Tournament Kelas IPS SMA Negeri 1 Teras Boyolali. Jurnal Pendidikan Sosiologi, 10 (1), 1-15.

Qomariyah, N. 2014. Penerapan Model Pembelajaran Guided Discovery Untuk Meningkatkan Keterampilan Proses Sains Siswa SMP Kelas VII. Jurnal Pendidikan Sains e-Pensa: ISSN 2252-7710. 2(1): 78-88.

Roestiyah N. K. 2008. Strategi Belajar Mengajar. Jakarta: Rineka Cipta.

Rohim, F. 2012. Penerapan Model Pembelajaran Discovery Terbimbing Pada Pembelajara Fisika Untuk Meningkatkan Kemampuan Berpikir Kreatif. Unnes Physics Education Journal, 1 (1), 1-7. 
Rukiyati, Nani Sutarini dan Priyoyuwono. 2014. Penanaman Nilai Tanggung Jawab dan Kerja Sama Terintegrasi dalam Perkuliahan Ilmu Pendidikan. Jurnal Pendidikan, IV(2) (Online), (www. journal. uny. ac. id), diakses 11 Januari 2019. 213-224.

Sari, E. N., Saiful, R., Nur, R. U. 2016. Pengaruh Model Pembelajaran Discovery Learning Dengan Mind Mapping Terhadap Hasil Belajar Siswa Pada Materi Sel Di SMA. Unnes Science Education Journal. 5 (3) (2016).

http://journal.unnes.ac.id/sju/index.php/usej

Sugiarto, Iwan. 2004. Mengoptimalkan Daya Kerja Otak Dengan Berpikir Holistik Dan Kreatif. Jakarta: Gramedia Pustaka Utama.

Sujana, A. 2014. Pendidikan IPA. Bandung: Rizqi Press.

Susanti dan Wulan, R. 2015. Pengaruh Penerapan LKPD Bebasis Discovery Learning Bebantuan Mind Map Terhadap Komperasi IPA Peserta Didik Kelas VII SMPN 6 Bukittinggi. Pillar of Physics Education, Vol 5. April 2015, 145-152.

Trianto. 2010. Model Pembelajaran Terpadu: Konsep, Strategi Dan Implementasinya Dalam Kurikulum Tingkat Satuan Pendidikan. Jakarta: Bumi Aksara.

Ulumi DF, Maridi \& Y Rinanto. (2015). Pengaruh Model Pembelajaran Guided Discovery Learning terhadap Hasil Belajar Biologi di SMA Negeri 2 Sukoharjo Tahun Pelajaran 2013/2014. Jurnal Pendidikan Biologi FKIP UNS, 7(2), 68-79.

Utami. 2017. Penerapan Strategi Discovery Learning (DL) Untuk Meningkatkan Keterampilan Berpikir Kritis Dan Pemahaman Konsep IPA. Jurnal Inovasi Pembelajaran. 3(1), 483-490.

Widiadnyana I W., Sadia I W dan Suastra I W. 2014. Pengaruh Model Discovery Learning Terhadap Pemahaman Konsep IPA dan Sikap Ilmiah Siswa SMP. EJournal Program Pascasarjana Universitas Pendidikan Ganesha Program Studi IPA 4 : 1-13. 